\title{
EXECUTIVE-LEGISLATIVE RELATIONS IN BRAZIL: Is 2009 The First Year of the Rest of OUR Lives?*
}

\author{
Relación Ejecutivo-Legislativo en Brasil: \\ ¿Es el año 2009 el primero del resto de nuestras vidas?
}

\section{LÚCIO RENNO}

University of Brasilia

\begin{abstract}
In evaluating the year of 2009 in Brazilian politics, this article focuses on what was the main political event of the year: the reform of Congress' Provisional Measures (MPVs) evaluation procedures. Through a very peculiar instrument of institutional reform, Michel Temer, President of the Chamber of Deputies, offered an alternative interpretation for the existing rule regarding the blockage of the legislative agenda (sobrestamento de pauta) by Provisional Measures. The new interpretation, also partially backed by the Supreme Court, may have affected the Executive Branch's use of Provisional Measures dramatically, reducing its reliance on MPVs as a policymaking instrument. In order to test this hypothesis, the article examines the patterns of MPV use before and after President Temer's new interpretation, contrasting the years of 2008 and 2009. Empirical evidence indicates, albeit still in preliminary fashion, that the reform did affect the Executive Branch's impetus to issue new Provisional Measures.
\end{abstract}

Key words: Provisional measures, institutional reform, Executive/Legislative relations.

\begin{abstract}
RESUMEN
En su evaluación de la política brasileña en el 2009 este artículo se enfoca en lo que fue el principal suceso político del año: la reforma de los procedimientos de evaluación de las medidas provisionales del Congreso (MPV). Haciendo uso de un particular instrumento de reforma institucional, Michel Temer, presidente de la Cámara de Diputados, ofreció una interpretación alternativa de la ley existente en torno al bloqueo de la agenda legislativa (sobrestamento de pauta) usando Medidas Provisionales. La nueva interpretación, parcialmente apoyada por la Corte Suprema, pudo haber afectado dramáticamente el uso por parte del Ejecutivo de Medidas Provisionales, reduciendo su dependencia en MPV como instrumento de toma de decisón política. Con el objetivo de probar esta hipótesis, el artículo examina el comportamiento en el uso de MPV antes y después de la nueva interpretación del presidente Temer, contrastando los dados de los años 2008 y 2009. Las evidencias empíricas indican que, aun estando en sus inicios, la reforma sí afecta el ímpetu del Ejecutivo en su uso de Medidas Provisionales.
\end{abstract}

Palabras clave: Provisionales, reforma institucional, relaciones Ejecutivo y Legislativo.

* I thank David Altman, Octavio Amorim Neto, Luiz Alberto dos Santos and Acir dos Santos Almeida for extremely helpful comments and suggestions. Remaining inconsistencies are my responsibility. 


\section{INTRODUCTION}

At first sight, 2009 was not an eventful year in Brazilian politics. There were no elections, no major scandals (at least not similar to prior years), the economy continued performing well, in spite of the international crisis, President Lula's popularity skyrocketed and he made it very clear to all that Dilma Rousseff would be the government's candidate in the 2010 presidential elections. Brazil also gained prominence in the international scenario, with, among other things, recognition coming informally from US President Barack Obama, who said that Lula is "the man". ${ }^{1}$ On the downside, urban violence continues to be a major concern of populations in the big Brazilian cities and a lingering problem in the political agenda, which will, certainly, resurface in the 2010 campaign.

All of this, however, is not terribly different from 2008, or, for that matter, from most of Lula's second term in office. In fact the past three years have seen great political stability and economic prosperity. There are evidences that targeted social policy programs and public policies increasing minimum wages and access to credit attenuated the longlasting problems of poverty and inequality (Neri, 2007; Singer, 2009). Furthermore, the economic stability achieved through the Real Plan, in 1994, has not been challenged: On the contrary, the Worker's Party administration embraced it and maintained the general outline of macro-economic management inaugurated by former President Cardoso. Hence, almost 15 years of economic stability, with accentuated investment in social policies in the last 7 years, have brought an extended period of stability both economic as well as political, never seen before in Brazilian history. In part, the very favorable configuration of domestic economic and political conditions has shielded Brazil from the much-talked-about international financial crises that haunted many countries in the Americas, Europe and Asia. Brazil was one of the last countries to feel the impact of the crises and one of the first to overcome it.

Regarding the year of 2009 more specifically, one could stress that Rousseff's grow in vote intentions and the emergence of a new scandal in the end of the year, involving the Governor of the Federal District, the only governorship held by the Democratas (DEM) party, a strong adversary of the PT administration, could also be highlights of 2009. However, both do not really play out until 2010 and will be decisive to explain the story of the general elections of that year. But, that is a different story, to be told in next year's review of Brazilian politics. Hence, the story one would expect to be told about 2009 is of a stable, even lackluster, economic and political scenario in Brazil.

However, first impressions, sometimes, are deceiving. The event that marks 2009 in Brazil was a major institutional reform, conducted in a very peculiar way, which may have altered Executive/Legislative relations in Brazil for good. Pundits and layman alike have not given it enough attention yet, maybe because it is still so recent or because it refers

1 Coverage of this event, which occurred during a G20 meeting in April 2009, was vastly documented. See http://blogs.abcnews.com/politicalpunch/2009/04/thats-my-man-ri.html (visited in April 22, 2010) for details. 
to a very technical issue. Still, given its potential impact in the conduction of politics in Brazil, it certainly deserves investigation and will be the focus of this article.

In a nutshell, in March of 2009, almost immediately after taking office as President of the Chamber of Deputies, Michel Temer, a Federal Deputy from the PMDB (Partido do Movimento Democrático Brasileiro) of Sao Paulo and an important leader of the governing coalition in Congress -potentially vice-presidential candidate and running mate of Dilma Rousseff in the 2010 elections- introduced through an unusual way a significant change in the evaluation procedures of Provisional Measures (MPV) in the Chamber of Deputies. ${ }^{2}$ Recall, Provisional Measures are a decree-like legislative prerogative of the Executive Branch in Brazil, similar in some ways to Executive Orders in the United States, to be used for urgent and extraordinary matters, but that has been widely applied instead to govern the country in an every-day basis (Power, 1998; Figueiredo and Limongi, 1999; Amorim Neto and Tafner, 2002; Reich, 2002; Amorim Neto, Cox and McCubbins, 2003; Negretto, 2004; Pereira et al., 2005, 2008; Almeida and Santos, 2008; Pachon, 2008; Palanza, 2009).

Provisional Measures have gained central stage in the last years in Brazil because of the frustrated 2001 reform, which aimed at reducing the use of MPVs, but ended up having the opposite effect; with a rise in the mean number of MPVs per month after its implementation and an even stronger control of the legislative agenda by the Executive Branch (Pereira et al., 2008). A key aspect of this reform was the blockage of the legislative agenda by MPVs, forcing the Chamber of Deputies to vote on it and forbidding that any other legislative proposal is discussed until the vote on the MPV is accomplished. Leaders in Congress extensively criticized this aspect of the Constitutional Amendment in the many years that followed, with accusations from members of all parties, not just the opposition, that the Executive Branch was abusing the use of MPVs and controlling the Legislative agenda even more now than before the blockage of the agenda by MPVs was instituted.

In 2009 this scenario may have changed dramatically. Through a very simple mechanism, a clarification to a Question of Order (Questão de Ordem) posed by another Federal Deputy, Michel Temer defined that the blockage of the legislative agenda would pertain only to a certain type of law proposal -Ordinary Law Proposals- and not all, and that extraordinary sessions could be requested to vote all the other types of legislative proposals -Constitutional Amendments, Complementary Law Proposals, Legislative Decrees, etc.independent of the presence of a MPV in the Order of the Day (Ordem do dia). Temer found a way, based on an alternative interpretation of Constitutional Amendment 32, which became article 62 of the Constitution, to revert the blockage of the legislative agenda imposed by MPVs. This, I argue, is quite an innovative way of conducting institutional reform! Not even with the swipe of a pen, but through a simple oral clarification to a question, registered in the Stenography Notes (Notas Taquigráfricas) of the Chamber of 
Deputies, Temer may have significantly contributed to change Executive/Legislative relations in Brazil. We will tell this story in this review of the year 2009 in Brazil and evaluate the impact of the institutional reform in the use of MPVs in the country before and after what we will refer to here as the Temer Reform.

\section{A ONE-MAN INSTITUTIONAL REFORM?}

The description above may lead one to think that Temer alone is responsible for this very important institutional reform that occurred in Brazilian politics in 2009. This is only partially accurate, and again first impressions do not make justice to the complexity of the process. True: Temer took the initiative to change the practice of how Congress deals with MPVs in 2009, but he was backed by a general mood favorable to change the role MPVs play in Brazil. The plot, therefore, has at least four major actors and three sequential acts.

\section{Act 1: The Antecedents}

Bottom line is, Congress was not satisfied with the end result of the 2001 reform of Provisional Measures procedures: This was expressed in many occasions and by many politicians, independent of political party. The intent of the 2001 reform, that resulted in Article 62 of the Constitution, was to end the possibility that the Executive Branch govern through MPVs without Congress explicitly manifesting itself about them. Prior to the 2001 reform, the Executive Branch could re-edit MPVs indefinitely. Once a MPV was published in the Official Diary of the Republic (Diário Oficial da União), and the Executive Branch can accomplish this by simply issuing the MPV, it gains force of law immediately. The MPV can only be reversed if Congress rejects it, if another law or MPV revises it or Courts question it. Therefore, once issued, the MPV has the force of law and the costs of reversing it are thrown, mostly, in Congress' lap.

Most of these factors have been left unchanged by the 2001 reform. What did change was the capability of the Executive Branch to reissue MPVs indefinitely: Constitutional Amendment 32 prohibited reissuing MPVs, a common practice before the reform that lead to a situation in which a MPV could be in existence for several years without the Legislative Branch ever positioning itself in relation to the MPV. Important economic reforms, like the Real Plan that stabilized the Brazilian economy in 1994, were implemented as Provisional Measures and reissued several times.

But, in order to force Congress to express itself regarding each and every new, original MPV issued by the Executive Branch, Constitutional Amendment 32 established that the Legislative agenda should be blocked after 45 days of the MPV issuance, forcing both houses in Congress to vote on it. No other legislative proposal, as was said above, could be voted on until the MPV at hand was voted. The blockage of the agenda was the trap that Congress set for itself without noticing. In 2008, the legislative agenda was blocked by MPVs in approximately $55 \%$ of the Deliberative Sessions, both ordinary 
and extraordinary, of the Chamber of Deputies. That is to say, there were more blocked sessions than unblocked ones.

It is true that re-issues were prohibited and that this was a relevant change and improvement achieved by the 2001 reform. However, there were significant unanticipated consequences of the reform that lead up to even greater discontent inside the Chamber of Deputies regarding MPVs. The most relevant and criticized aspect of the 2001 reform was the blockage of the agenda by MPVs. Apparently, the Executive Branch took advantage of this and increased the monthly average emission of original MPVs after the reform, in comparison to the period immediately before it, increasing its predominance over Congress' agenda (Pereira et al., 2008).

This dissatisfaction was clearly voiced by the President of the Senate, Garibaldi Alves in 2008, an important supporting actor in this story. As early as March 2008, Senator Alves was quite loudly expressing his dismay with the excessive use of MPVs by the Executive Branch. In an interview, he states that President Lula, like all of his predecessors, uses MPVs beyond what is constitutionally defined. According to him, MPVs should be issued only in exceptional moments and not to advance policy and laws that should otherwise be presented as Ordinary Law Proposals. ${ }^{3}$ Senator Alves' declared dissatisfaction with the exaggerated use of MPVs turned into action in the end of 2008, when he returned to the Executive Branch a Provisional Measure that, in his view, did not meet the "need and urgency" criteria established by the Constitution. This was only the second time in contemporary Brazilian history that the Legislative Branch returned a MPV to the Executive Branch. ${ }^{4}$ It was, no doubt, a clear message to the Executive Branch that Congress was extremely unhappy with the alleged excessive use of MPVs. It was also a major manifestation of Congress' discomfort regarding MPVs abusive use after the 2001 reform.

Furthermore, in 2008 the Supreme Court (Supremo Tribunal Federal - STF) had also been called to intervene in the dispute between the Executive and Legislative Branches over the use of MPVs. After the Direct Action of Unconstitutionality 4048 (Ação Direta de Inconstitucionalidade - ADI) proposed by the Partido da Social Democracia Brasileira (PSDB) to the STF, the court ruled by majority vote that MPVs could only be used as a mechanism to reallocate budgetary funds in moments of crises, to cover unexpected and urgent expenses. The Supreme Court considered unconstitutional MPV 405 that transferred budgetary funds to current expenses of the government. The Executive Branch routinely used MPVs do perform such budgetary transfers. After the SFT ruling, the reliance on MPVs to reallocate budgetary funds diminished significantly. Hence, the STF 2008 ruling on MPVs reinforced the general feeling contrary to MPV use.

3 "Garibaldi: medidas provisórias deveriam ser editadas apenas em casos excepcionais", from Agencia Senado, March 19, 2008 (Consulted on April 26, 2010).

4 "Presidente do Senado devolve ao governo Lula MP da filantropia", written by Gabriela Guerreiro, from Folha Online, November 19, 2008 (Consulted on April 26, 2010). 
These events end the first scene of this story and set the scenario for what is to come, when Michel Temer takes central stage. ${ }^{5}$

\section{Act 2: The Reform}

Michel Temer won the presidency of the Chamber of Deputies in February 2009, substituting Arlindo Chinaglia, also from Sao Paulo, but from Lula's Partido dos Trabalhadores (PT). Even though Chinaglia had already expressed consternation with the excessive use of MPVs, the core debate in his presidency was one of electoral system reform and not of Executive/Legislative relations. Temer, on the other hand, "hit the ground running" and in his first month as President of the Chamber, in March 17, 2009, attempted to radically change how the Executive and Legislative Branches conduct politics in Brazil.

In March $17^{\text {th }}$, Temer responded to a question posed by Federal Deputy Regis de Oliveira (PSC/SP) about the interpretation of the Constitution's paragraph 6 of Article 62 that emanated from Constitutional Amendment 32. The question was about what type of legislative proposal should be affected by the blockage of the Legislative agenda imposed by MPVs after its $45^{\text {th }}$ day of processing in Congress. Temer responded that not just Resolution Proposals, which was the motivation of Oliveira's Question of Order, but also Constitutional Amendment Proposals, Complementary Law Proposals and Legislative Decree Proposals are not affected by the blockage of the legislative agenda. ${ }^{6}$ Temer went on to argue that there are both political as well as judicial reasons for a more flexible interpretation of the referred paragraph.

The political justification was based on the fact that Congress had not been able, because of the excessive number of MPVs, to evaluate any other type of legislative proposal until then in that year (March) and it probably wouldn't be able to focus on anything else but MPVs for the remaining of the semester and probably the year. In other words, the reason for the change in interpretation of paragraph 6 of article 62 is simple: Congress had suffered tremendous autonomy losses to define its own agenda because of the abusive use of MPVs by the Executive Branch. The blockage of the agenda, a mechanism to force the Legislative Branch to be heard, instead tied its hands and further made it hostage of the Executive Branch's proposals. It was against this state of affairs that Temer reacted, as he clearly states in his response to Deputy Oliveira, further stressing that he spoke not as a leader of government or the opposition, but as President of the Chamber of Deputies.

The second justification for his interpretation was of a judicial nature. Temer starts by pointing out that exceptions in laws should be treated in a restrictive and not a broad, encompassing way. The power of issuing MPVs by the Executive Branch in itself is an exception in the Constitution regarding separation of powers. According to Temer, the

5 It is important here to highlight that the debate regarding the use of MPVs has been occurring for many years after the 2001 reform and prior to Alves' actions.

6 This explanation is documented in the stenographical notes of Session 037.3.53.O of March 17, 2009, pps. 214 to 221 . 
Brazilian Constitution is clear: the power to legislate belongs to the Legislative Branch and not the Executive Branch. Furthermore, the new interpretation Temer suggests is based on a systemic view of the Constitution, meaning that the literal interpretation of each and every paragraph of every article in all laws cannot and should not be done independently from the general interpretation of the Constitution and its most relevant goals. For Temer, the most important goal of the Brazilian 1988 Constitution is to establish a democratic state based on the rule of law and separation of powers.

Therefore, to assure that the Legislative Branch regains its autonomy vis-à-vis the Executive Branch, Temer concluded that only one type of legislative proposal should be blocked by MPVs: Ordinary Law Proposals, because these, in most cases, are the only other legislative instrument that deals with issues and topics that Provisional Measures can also address. Hence, MPVs and Ordinary Law Proposals, in the case of most topics, can be used interchangeably. This is not the case with MPVs and Constitutional Amendments, Complementary Law Proposals, Legislative Decrees and Legislative Resolutions. MPVs cannot deal with matters that can be exclusively legislated in the forms above. Following Temer's reasoning, the blockage only applies to legislation that is equivalent to Provisional Measures. All other types of legislation can be voted in extraordinary sessions, to be defined by the President of the Chamber. The interpretation of paragraph 6 can only be understood, therefore, in light of the types of legislation that MPVs can substitute. Only Ordinary Laws, in some topics, are interchangeable with MPVs. Hence, only Ordinary Law Proposals should be affected by the blockage of the legislative agenda caused by MPVs.

Temer concluded his thoughts pointing out that he had discussed this issue with political party leaders, in their meeting to define the agenda of the day. Some leaders disagreed with his interpretation and stated they would question the decision in the Supreme Court. Temer welcomed the idea and stimulated that the Supreme Court be brought in to further discuss the issue.

With this position of defiance, we end act two and move to a different setting in the final act: The plot thickens and now unfolds in the Supremo Tribunal Federal.

\section{Act 3. The Aftermath}

In the final act, the actors now are the leaders of the three largest opposition parties in Congress, the Partido Popular Socialista (PPS), the Democratas party (DEM) and the Partido da Social Democracia Brasileira (PSDB). Together they attempt to challenge Temer' interpretation of the Constitution by advancing a Writ of Mandamus (Mandato de Seguranca) to the Supreme Court, requesting it's evaluation of the constitutionality of Temer's decision on MPVs and legislative agenda blockage. I will consider the trio here as our third actor in this process. The last actor is the Supreme Court and it's positioning in relation to Temer's interpretation.

On March 18th, the leaders of the minority in the Chamber questioned Temer's decision in the courts. They did not disagree fundamentally with Temer's intent, agreeing that there is an abuse in the use of MPVs and that the Legislative Branch has lost autonomy 
in controlling its own agenda. But they disagreed with the solution proposed by Temer. The main criticism is that the proposed interpretation is not the best solution to the problem because it still blocks the thousands of Ordinary Law Proposals, most elaborated by Federal Deputies, of being assessed by the Chamber of Deputies. ${ }^{7}$ In addition, the opposition leaders pointed out to contradictions in the systemic interpretation of the Constitution proposed by Temer, stating that there are other instances in the Constitution that require the need for the blockage of the Legislative agenda and that Temer ignored these instances. For instance, Temer's interpretation completely disregards the situation of urgency petitions by the President and the appreciation of Presidential vetoes after 30 days, both leading to the blockage of the agenda, independent of legislation type. Finally, the leaders of the opposition parties argued that the blockage of the legislative agenda is an important tool for the minority and that it should not be threatened in any way or form. Therefore, the motivation to question Temer's decision was both of a substantive as well as procedural nature.

On March 27th the Supreme Court, through Justice Celso de Mello's response to the Security Mandate of the opposition leaders, supported Temer's interpretation. ${ }^{8}$ Justice Mello argued that Temer's justifications were justifiable in both political as well as legal grounds. Justice Mello insisted that Temer's interpretation assured the separation of powers as it is expressed in the Federal Constitution of 1988. Furthermore, Justice Mello stressed that the Executive Branch has consistently misinterpreted the Constitution by relying in MPVs as an ordinary and not an extraordinary means of policy-making in Brazil. Temer's decision, in Justice Mello's view, therefore, strives to balance the relationship between the Executive and Legislative Branches and aims at reducing the hegemony of the former in affecting the legislative agenda. Justice Mello is extremely clear in his argumentation: Temer's decision aids in restoring the Legislative Branch's control over it's own agenda and reduces the Executive Branch's propensity to govern through Provisional Measures.

After Justice Mello's statement, the process continued it's processing in the Supreme Court, with several petitions and citations taking place. Finally, in December 16, 2009, Justice Cármen Lúcia Antunes Rocha, asked to review the entire process. The court is now waiting for her position in order to cast a final vote, which hasn't occurred yet. ${ }^{9}$

The Supreme Court, just like it did in 2008, when it restricted the use of MPVs for budgetary credit reallocations, again signaled its agreement with Congressional leaders that the Executive Branch has abused the use of MPVs and, in that way, has controlled the legislative agenda of Congress. Clearly, even though Temer does play a key role in the process of revising MPVs processing in the Chamber of Deputies, this is a process that involves many actors, in both Congress and the Judiciary Branch.

For the justification of the opposition leaders, see Mandato de Segurança (MS 27931).

For the full response see Medida Cautelar em Mandato de Segurança 27.931-1.

As of now, April 2010, the Supreme Court has not finalized the processing of the Security Mandate. 
The question that obviously comes to mind is: has the proposed new interpretation and the constant and clear messages of disapproval sent by Congress and the Judiciary regarding the exaggerated use of MPVs affected the issuing of such measures by the Executive Branch?

\section{THE EMPIRICAL EFFECTS OF THE TEMER REFORM}

Albeit still waiting for a final decision of the Supreme Court, the backing of Justice Mello has strengthened Temer's reinterpretation of the Constitution regarding Provisional Measures. The question now is, has this revision of the law influenced the use of MPVs and how the Executive Branch approaches the legislative process in the Chamber of Deputies? That is, was there a reduction in the number of MPVs in 2009, after the so-called Temer Reform? Has the Executive Branch increased the presentation of Ordinary Law Proposals, instead of MPVs in recognition of the dissatisfaction the latter causes in Congress?

Data below, coming from both the Chamber of Deputies and Presidency of the Republic websites leave no margin for doubt that the Temer Reform had a an impact in the use of MPVs in Brazil. This happened holding constant several traits of the Executive/Legislative relations in Brazil, such as cabinet composition and size of the governing coalition in Congress, as well as economic conditions in the country.

Hence, in order to isolate the impact of the reform, we first provide evidences that there were no significant changes in the economic and political scenario between 2008 and 2009 in Brazil that could of affected Executive/Legislative relations. We then move on to verify if there were changes in the use of MPVs and Ordinary Law Proposals by the Executive Branch. This is, therefore a preliminary attempt to isolate the potential effect of the Temer Reform on Provisional Measure usage in Brazil.

Table 1 indicates the composition of the Chamber of Deputies by political party. The conclusion is obvious: there aren't significant differences between 2008 and 2009.

The composition of the cabinet did not change between 2008 and 2009 either, with the distribution of cabinet positions remaining stable across members of the coalition. ${ }^{10}$ Hence, it is reasonable to argue that the relationship between executive and legislative branches, given the lack of significant changes in the governing coalition, did not change in the two years.

Furthermore, as was argued before, economic and social conditions in Brazil continued improving or remained stable in 2009, in spite of the international financial crises that affected many countries in the region. Figure 1 indicates inflation levels, as measured by the Indice de Preços ao Consumidor of Fundação Getúlio Vargas (IPC-FGV), which further attests the sustainable economic stability Brazil has achieved.

10 For information on the ministers and the dates they occupied their positions in the cabinet, see the website: http://www.presidencia.gov.br/info_historicas/galeria_pres/Lula2/index_html_interna/. 
Table 1: Number of Seats by Political Party in the Chamber of Deputies: Brazil 2008-2009

\begin{tabular}{|c|c|c|}
\hline Party & $\begin{array}{c}\text { Number of } \\
\text { Seats in } 2008\end{array}$ & $\begin{array}{l}\text { Number of } \\
\text { Seats in } 2009\end{array}$ \\
\hline Bloco MPVDB, PTC & 92 & 92 \\
\hline$\underline{\mathrm{PT}}$ & 80 & 79 \\
\hline$\underline{\text { PSDB }}$ & 59 & 58 \\
\hline$\underline{\mathrm{DEM}}$ & 56 & 56 \\
\hline Bloco PSB, PCdoB, MPVN, PRB & 49 & 49 \\
\hline$\underline{\mathrm{PR}}$ & 41 & 41 \\
\hline$\underline{\mathrm{PP}}$ & 41 & 41 \\
\hline$\underline{\text { PDT }}$ & 25 & 23 \\
\hline$\underline{\text { PTB }}$ & 19 & 22 \\
\hline$\underline{\text { PSC }}$ & - & 16 \\
\hline$\underline{\text { PPS }}$ & 13 & 15 \\
\hline$\underline{\mathrm{PV}}$ & 14 & 14 \\
\hline$\underline{\text { PSOL }}$ & - & 3 \\
\hline$\underline{\text { PHS }}$ & - & 3 \\
\hline$\underline{\text { PTdoB }}$ & - & 1 \\
\hline Others & 24 & - \\
\hline Total & 513 & 513 \\
\hline
\end{tabular}

Source: For 2008, Anastasia e Melo (2009). For 2009, website of the Câmara dos Deputados: http:/ / www2.camara.gov.br/deputados/liderancas-e-bancadas (Consulted on April 23, 2010). Table constructed by the author.

Figure 2 presents the data on real minimum wages in Brazil, based on Reais, and correcting for inflation measured as the Índice Nacional de Preços ao Consumidor (INPC) of the Instituto Brasileiro de Geografia e Estatística (IBGE). It is clear that there were salary gains for Brazilian workers in the past couple of years.

Figure 3 presents data on unemployment level measured in the metropolitan regions of Recife, Salvador, Belo Horizonte, Rio de Janeiro, São Paulo and Porto Alegre. Again, there is a slight tendency of decrease in unemployment, but it is kept stable varying between $7 \%$ and $9 \%$.

It must be said, too, that the positive macro-economic scenario, described by the data above, in a period of a deteriorating international economic conditions, are in part a consequence of Lula's administration's efforts to curb the impact of the international 
Figure 1: Inflation: Brazil, 2008-2009

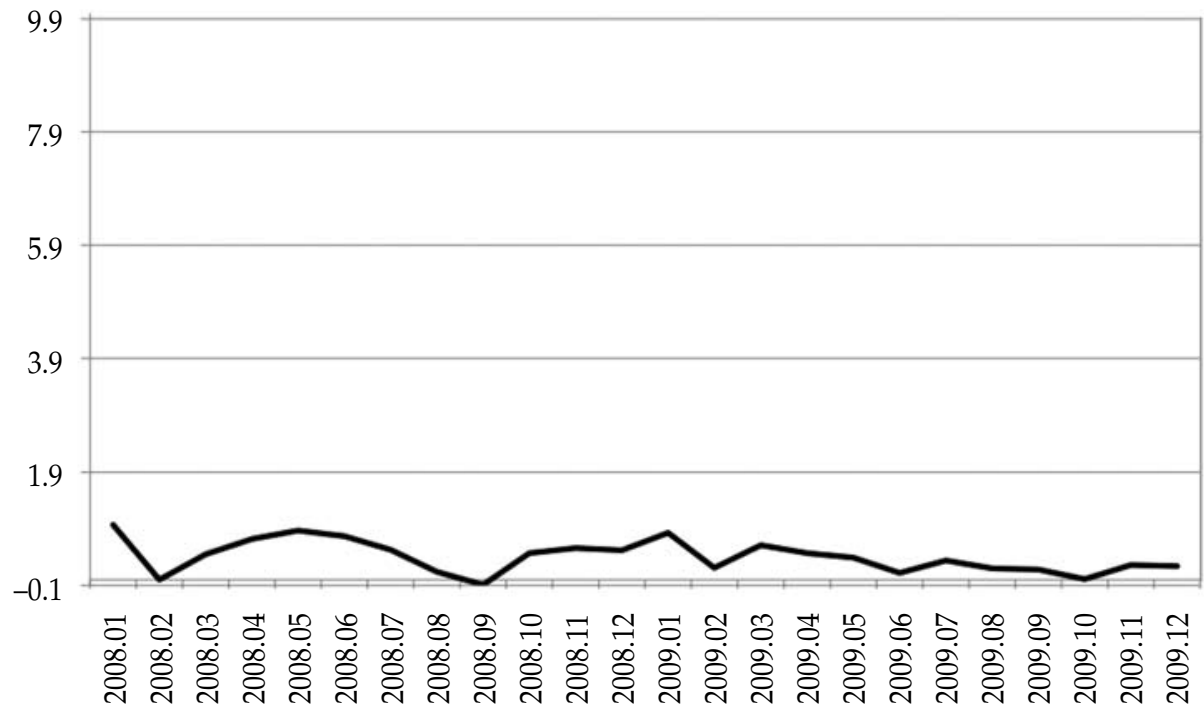

Source: Ipeadata: www.ipeadata.gov.br (Consulted on April 26, 2010). Graph constructed by the author.

Figure 2: Real Wages in Reais (R\$): Brazil, 2008-2009

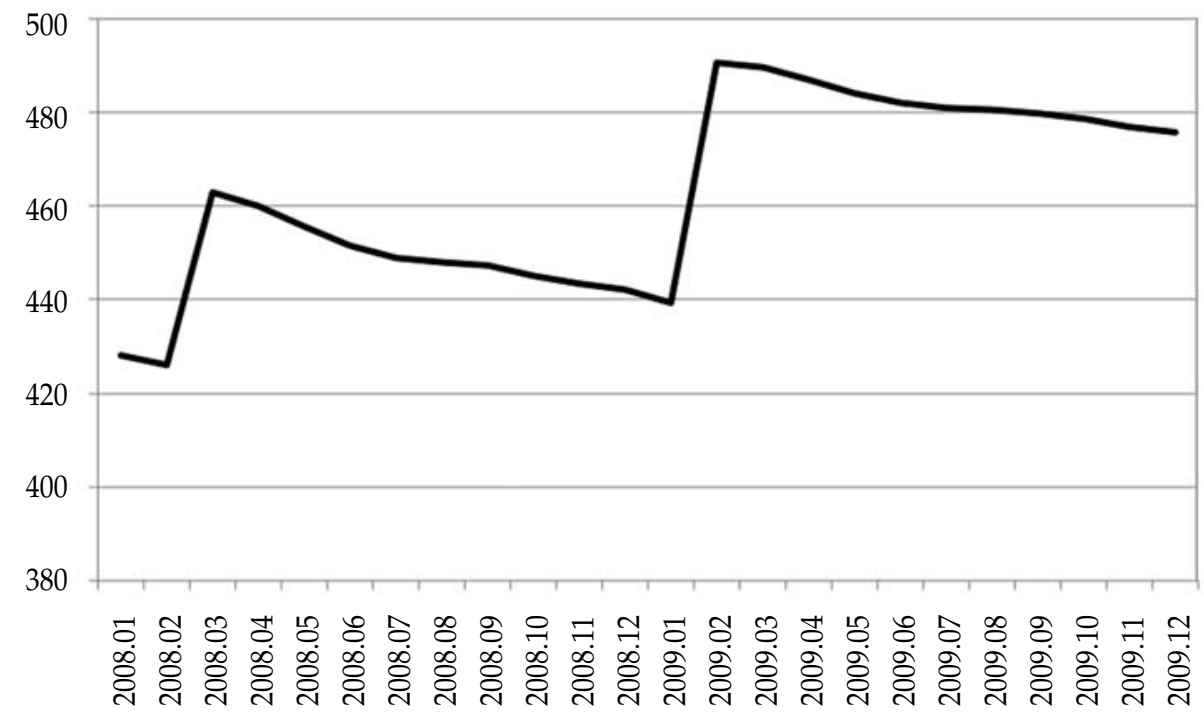

Source: Ipeadata: www.ipeadata.gov.br (Consulted on April 26, 2010). Graph constructed by the author. 
Figure 3: Unemployment Level: Brazil, 2008-2009

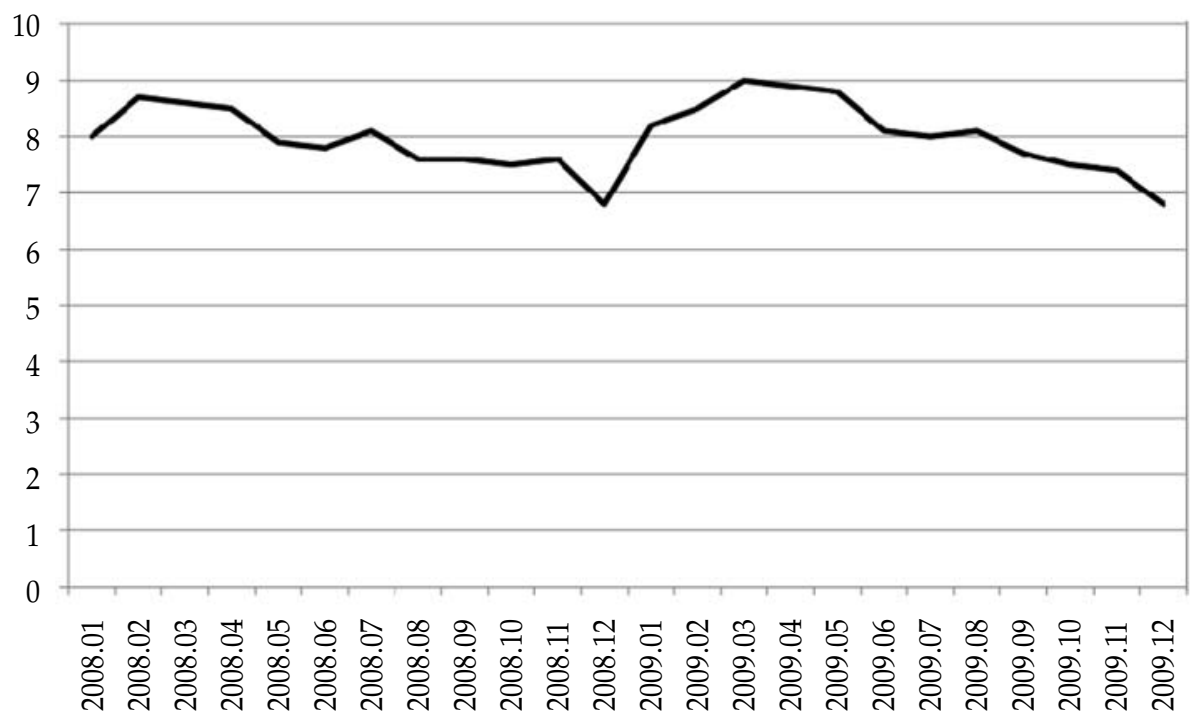

Source: Ipeadata: www.ipeadata.gov.br (Consulted on April 26, 2010). Graph constructed by the author.

financial crises in Brazil. Yes, Brazil did have a very high stock of international reserves when it entered the crises and the economy was stable, but some actions were directly taken to attenuate the impact of economic turbulence coming from abroad. Some of these procedures were rightfully implemented using Provisional Measures, given their urgent and emergent need. Overall, through MPVs the government adopted aggressive anti-cyclical fiscal and monetary policies. For instance, between 2008 and 2009 the government issued MPVs that changed the tax system, reducing tax burden in the production sector and opened lines of credit benefiting specifically the state-owned Banco Nacional de Desenvolvimento Econômico e Social -BNDES- so that it could provide credit to the population at lower interest rates. Hence, measures were taken, through several policy-making mechanisms, including MPVs to attenuate the effect of the international economic crises in Brazil.

As a consequence, in part, of the positive economic outcomes listed above, and also of President Lula's personal charisma, his popularity has reached record levels in 2009, as can be seen in Figure 4. Lula is renowned for his personal style of governing and rhetoric, based on a straightforward posture, open dialogue with politicians of the government and opposition alike and already famous metaphors between soccer and politics, which do resonate well with the median Brazilian voter. 
Figure 4: President Lula's Popularity: Brazil, 2008-2009

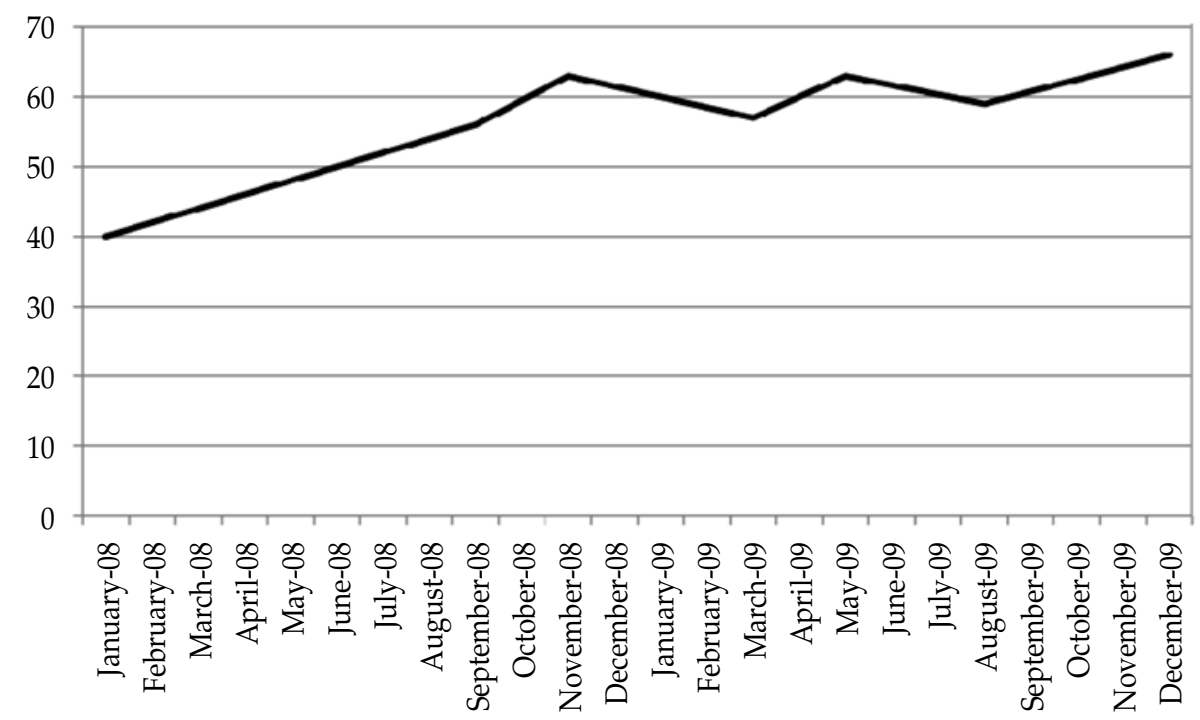

Source: DataFolha. I thank Timothy Power for collecting and coding the data and generously sharing it. Graph constructed by the author.

Therefore, there are no relevant changes between 2008 and 2009 in the political and economic settings, creating a perfect situation to isolate the impact of the institutional reform established very creatively by Deputy Michel Temer and backed by the Supreme Court. If at all, the changes that do exist, especially regarding the economy and the president's popularity increase his leeway to implement policy through extraordinary mechanisms of legislating (Pereira et al., 2005). Therefore, we load the dices against the main hypothesis of this study.

Figure 5 below presents the variation in use of MPVs per month in 2008 and 2009. Visual inspection of the figure indicates that the levels of variation before the Temer Reform were apparently higher than after and that there was a slight decrease in the use of MPVs after March. This pattern is interrupted, however, in December of 2009, which sees a spike in the issuing of MPVs. Hence, there is some indication of a change in patterns in the use of MPVs.

We test the hypothesis that the Temer Reform changed the pattern of reliance on MPVs by first performing a simple difference in means $t$ test contrasting the period before the reform, January 2008 to February 2009 with after the reform, until December of 2009. Table 2 presents the results, which attest that there was a decrease in the use of MPVs in 2009, after the Temer Reform in March. 
Figure 5: Provisional Measures: Brazil, 2008-2009

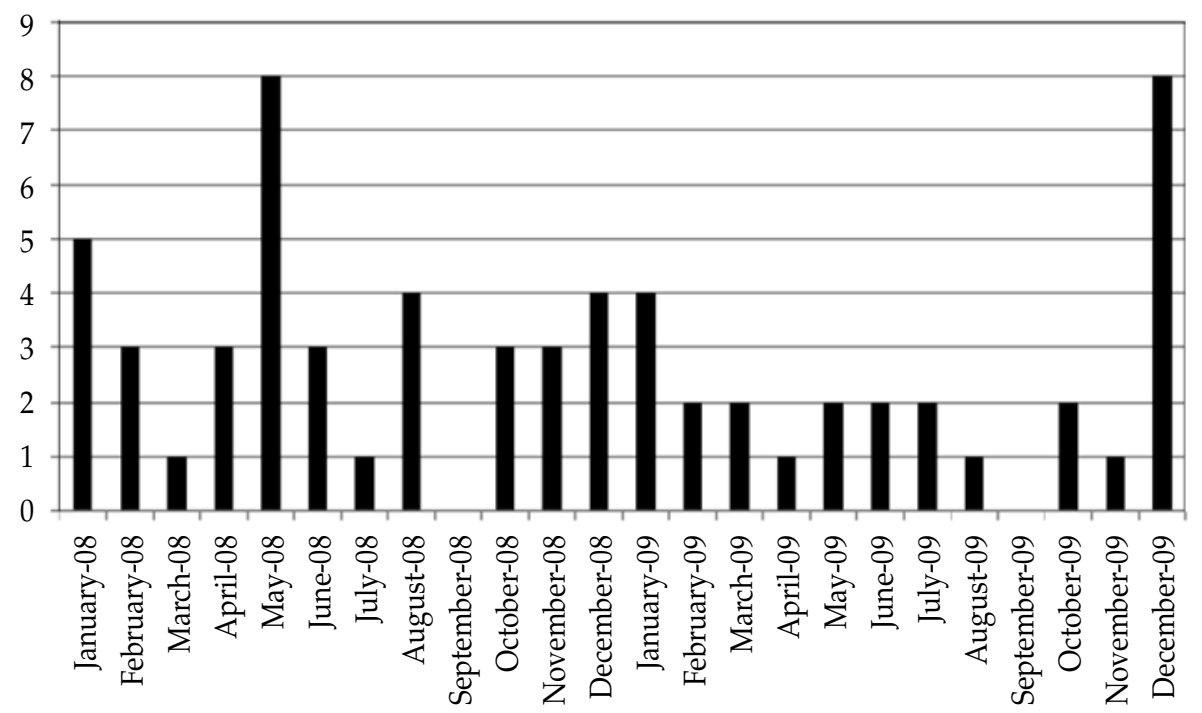

Source: Presidency of the Republic website, https://www.planalto.gov.br/ccivil_03/MPV/ Quadro/_Quadro\%20Geral.htm\#posterioremc (consulted on April 15, 2010). Coding of MPVs per month conducted by the author. Graph constructed by the author.

Table 2: T-Test of Difference in Mean contrasting the number of Provisional Measures: Brazil, 2008-2009

\begin{tabular}{lclll}
\hline \multicolumn{1}{c}{ Group } & Observations & \multicolumn{1}{c}{ Mean } & Std. Err. & Std. Dev. \\
\hline Before the Reform & 14 & 3.142857 & 0.5226427 & 1.95555 \\
After the Reform & 10 & 2.1 & 0.6904105 & 2.18327 \\
Combined & 24 & 2.708333 & 0.4234056 & 2.074256 \\
Difference & & 1.042857 & 0.8495115 & \\
\hline
\end{tabular}

Source: Presidency of the Republic website, https://www.planalto.gov.br/ccivil_03/ MPV/Quadro/_Quadro\%20Geral.htm\#posterioremc (consulted on April 15, 2010). Coding of MPVs per month and table constructed by author. Table constructed by the author.

The data above indicates that there was a difference greater than zero in the use of MPVs comparing before and after the reform, restricting the analysis to 2008 and 2009. The difference is statistically significant at the .11 level in a one-tailed test. The $t$ statistic has the value of 1.22 with 22 degrees of freedom.

Given that the variable is a positive count of MPVs, Table 3 presents results of Poisson Regressions to check the reliability of the findings above. In model 1, the Temer Reform is statistically significant at the .12 when the entire period is analyzed, so it approximates the usually accepted levels of statistical significance. When two months that are outliers, 
having many more MPVs than the rest (May 2008 and December 2009) are excluded from the analysis, the impact of the Temer reform is larger and statistically significant at the .05 level, which can be seen in model 2. Model 3 finally tests if the Temer Reform further reinforced the Supreme Court 2008 ruling that restricted the use of MPVs as a tool to reallocate budgetary funds through extraordinary credit requests. In this model, only MPVs that do not include extraordinary credit requests are compared before and after the reform. The variable indicating the Temer Reform is statistically significant to the 0.116 level, approximating acceptable statistical significance. In model 4 the outlying months are removed and the comparison before and after the reform is only between original MPVs without credit requests. The results further confirm that there was a significant decrease after the Temer reform in comparison to the period immediately before.

Table 3: $\quad$ Poisson Coefficients for Provisional Measures, Brazil 2008-2009

\begin{tabular}{lcccc}
\hline \multirow{4}{*}{ Variables } & $\begin{array}{c}\text { Provisional } \\
\text { Measures } \\
\text { Entire }\end{array}$ & $\begin{array}{c}\text { Provisional } \\
\text { Measures } \\
\text { No }\end{array}$ & $\begin{array}{c}\text { Provisional } \\
\text { Measures } \\
\text { No Credit } \\
\text { Period }\end{array}$ & $\begin{array}{c}\text { Provisional } \\
\text { Measures } \\
\text { No Outliers/ } \\
\text { Credit }\end{array}$ \\
\hline Model 1 & Model 2 & Model 3 & Model 4 \\
Constant & -0.40 & $-0.65^{* *}$ & -0.58 & $-0.83^{* * *}$ \\
& $(0.27)$ & $(0.32)$ & $(0.37)$ & $(0.27)$ \\
& $1.15^{* * *}$ & $1.02^{* * *}$ & $1.05^{* * *}$ & $0.93^{* * *}$ \\
& $(0.15)$ & $(0.17)$ & $(0.17)$ & $(0.16)$ \\
\hline
\end{tabular}

Observations 24 22 24 22

Robust standard errors in parentheses ${ }^{* * *} \mathrm{p}<0.01,{ }^{* *} \mathrm{p}<0.05,{ }^{*} \mathrm{p}<0.1$

Finally, was there a change in the Executive Branch's strategy of proposing Ordinary Laws after the reform? Did the reduction in the Executive Branch's reliance on MPVs result in an increase in Ordinary Law Proposals? Figure 6 does not present any clearly discernable pattern before and after the Temer Reform.

Table 4 presents the results of another difference in means $t$ test focusing on the frequency of use of Ordinary Law Proposals (PL) by the Executive Branch. There are no statistical or substantive differences between before and after the reform.

Hence, the Executive Branch has reduced its propensity to emit Provisional Measures, and has maintained its pattern of presenting Ordinary Law Proposals. Overall, this leads to more reliance in PLs after the Temer Reform, than before. However, it is important also to note that the number of Ordinary Law Proposals per month originated in the Executive Branch exceeds the mean number of Provisional measures in both periods. Therefore, the Executive Branch does not resort exclusively to Provisional Measures, as one might think, given the antecedents of the Temer Reform, but also uses ordinary mechanisms of legislating to advance its agenda. 
Figure 6: Ordinary Law Proposals of the Executive Branch: Brazil, 2008-2009.

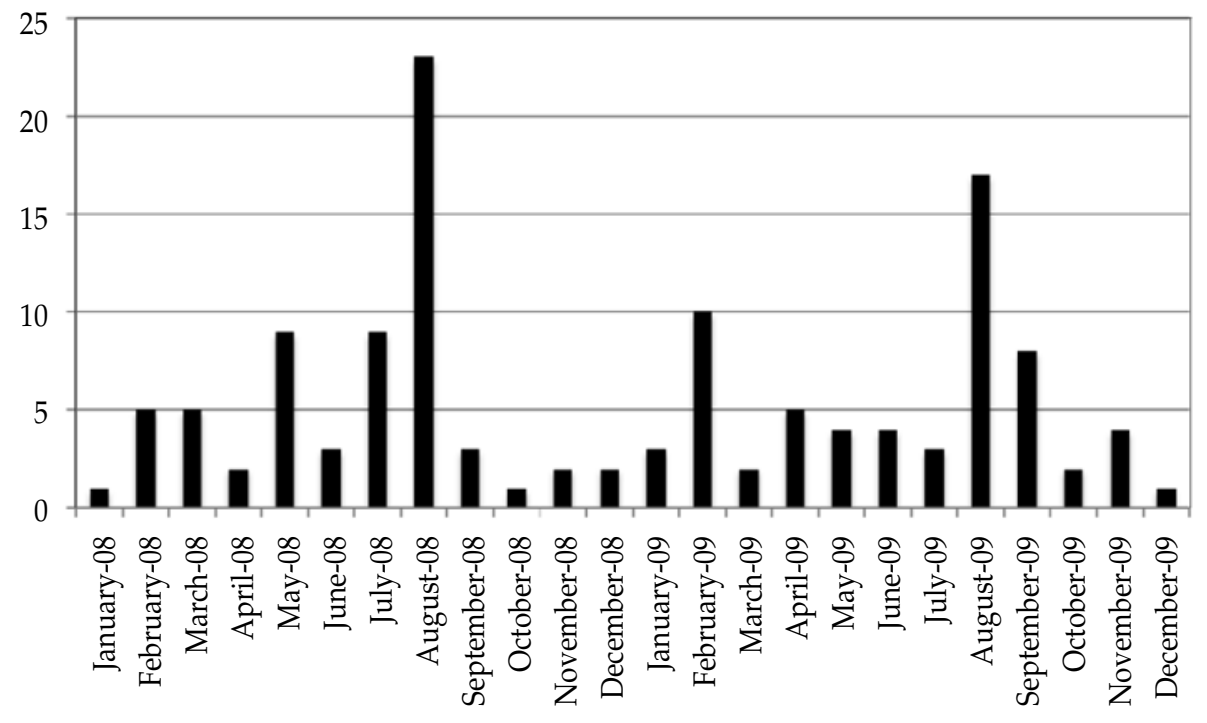

Source: Chamber of Deputies website, http://www.camara.gov.br/internet/sileg/default.asp (consulted on April 23, 2010). Graph constructed by the author.

Table 4: T-Test of Difference in Mean contrasting the number of Ordinary Law Proposals by the Executive Branch in 2008 and 2009

\begin{tabular}{lclll}
\hline \multicolumn{1}{c}{ Group } & Observations & \multicolumn{1}{c}{ Mean } & Std. Err. & Std. Dev. \\
\hline Before the Reform & 14 & 5.571429 & 1.567928 & 5.86665 \\
After the Reform & 10 & 5 & 1.468181 & 4.642796 \\
Combined & 24 & 5.333333 & 1.079564 & 5.288763 \\
Difference & & 0.5714286 & 2.235653 & \\
\hline
\end{tabular}

Source: Chamber of Deputies website, http://www.camara.gov.br/internet/sileg/default.asp (consulted on April 23, 2010). Coding of MPVs per month and table constructed by author. Table constructed by the author.

\section{CONCLUSION}

The year of 2009 in Brazil was apparently boring: the political and economic setting remained stable, without any major interruption in the functioning of the political system. Overall, there were no relevant changes in the governing coalition, with the maintenance of a similar distribution of power between government and opposition inside the Legislative and Executive Branches when compared to 2007 and 2008 (Amorim Neto and Coelho, 2008; Anastasia e Melo, 2009). Furthermore, the economy continued to perform well and Lula's popularity soared. 
This apparent tranquility, however, was interrupted by a significant institutional reform that occurred in early 2009. As soon as Federal Deputy Michel Temer took office as the President of the Chamber of Deputies, one of his first initiatives was to challenge the existing interpretation of the evaluation procedures of Provisional Measures by Congress. The Temer Reform, as I refer to it here, was conducted in an innovative way, without major debates and votes in the Chamber of Deputies. It was the result of a simple reinterpretation of the Constitution offered by Temer, the then recently elected President of the Chamber of Deputies, and later partially backed by the Supreme Court. The Temer Reform decreased the scope of legislative agenda blockage by Provisional Measures and very strongly signaled to the Executive Branch that Congress was overwhelmed by the excessive use of MPVs. The Supreme Court, through the positioning of one of its Justices, reaffirmed the belief that Congress no longer controlled its own agenda and that the Executive Branch was usurping legislating power from the Legislative Branch.

Did this new interpretation affect the use of MPVs in 2009 and change executive-legislative relations in Brazil? Results are still preliminary, but tend to indicate that there was a reduction in the use of MPVs in 2009. An exception to this pattern occurred in December of 2009, when the Executive Branch issued eight new Provisional Measures, reaching the levels prior to 2009. The legislative agenda has also been blocked more times than not in 2009, as it did in 2008.

In spite of its still unfinished nature, given that the Supreme Court still needs to cast a final vote on it, the reform discussed here was certainly the main event of Brazilian politics in 2009. Probably this issue will emerge in 2010 again, when the Supreme Court ought to have a final vote on the matter.

Furthermore, the legislative agenda has been blocked for about $55 \%$ of all deliberative sessions in 2009. Hence, the issue of Executive Branch control over the Legislative agenda is not completely solved by the Temer Reform. It is important now to go back further in time, and analyze MPV use in all years after the 2001 reform, to contrast how the events of 2008 and 2009 have influenced Executive/Legislative relations in Brazil and to attempt to disentangle how each of the current events discussed here - the Supreme Court ruling prohibiting extraordinary credit requests through MPVs, the return of the MPV to the Executive Branch by Senator Alves and the Temer's reinterpretation of the law - have influenced the use of MPVs. Clearly, there seems to be a significant reaction by the Legislative Branch, backed by the Supreme Court, in reducing the usage of MPVs by the Executive Branch in Brazil since 2008. Preliminary evidence indicates that MPV usage has fallen, but a longer time series is important to come to a final conclusion on this question.

Again, for a complete answer to this question, it is necessary to go back further in time to investigate if 2008 was not already contaminated by the reactions that occurred a bit prior to the Temer Reform. But, this is a task for future work. What is left unquestioned after the analysis above is that 2009 is marked by a strong reaction from the Legislative Branch regarding the use of Provisional Measures by the Executive Branch, with potential long-lasting effects in Brazilian politics. 


\section{REFERENCES}

Almeida, Acir and Santos, Fabiano. 2008. "Assymetric Information and Legislative Process: The Politics of Presidential Decrees in Brazil". Unpublished Manuscript.

Amorim Neto, Octávio, Gary D. Cox, and Mathew D. McCubbins. 2003. "Agenda Power in Brazil's Câmara dos Deputados, 1989 to 1998 ". World Politics, 55 (July), No 4.

Amorim Neto, Octávio and Paulo Tafner. 2002. “Governos de coalizão e mecanismos de alarme de incêndio no controle legislativo das medidas provisórias". Dados, 45, pp. 5-58.

Amorim Neto, Octávio and Coelho, Carlos Frederico. 2008. "Brasil en El 2007: El Desencuentro entre la Economia y la Politica". Revista de Ciencia Política, 28:1, pp. 81-102.

Anastasia, Fátima and Melo, Carlos Ranulfo. 2009. "Brasil: Dos Décadas de Democracia”. Revista de Ciencia Política, 29:2, pp. 275-300.

Figueiredo, Argelina, and Fernando Limongi. 1999. Executivo e Legislativo na Nova Ordem Constitucional. Rio de Janeiro: Editora Fundação Getúlio Vargas.

Negretto, Gabriel L. 2004. "Policy Making by Decree in Latin America: The Cases of Brazil and Argentina". Comparative Political Studies, 37:5 (June), pp. 531-562.

Neri, Marcelo. 2007. "Poverty, Inequality and Income Policies: Lula's Real". Ensaios Econômicos, Escola de Pós Graduação em Economia da Fundação Getúlio Vargas, Nº 662.

Pereira, Carlos, Timothy J. Power, and Lúcio Renno. 2005. “Under What Conditions Do Presidents Resort to Decree Power? Theory and Evidence from the Brazilian Case". Journal of Politics, 67: 1 (February), pp. 178-200.

Pereira, Carlos, Timothy J. Power, and Lúcio Renno. 2008. "Agenda Power, Executive Decree Authority, and the Mixed Results of Reform in the Brazilian Congress". Legislative Studies Quarterly, 34, pp. 5-34.

Pachón, Monica. Cross-avenue politics: the case of Colombia and Brazil. Thesis (Ph. D.) University of California, San Diego, 2008.

Palanza, Valeria. "Lawmaking In Brazil: Decrees vs. Statutes", Paper Presented at the Latin American Studies Association Meeting, Rio de Janeiro, Brazil, 2009.

Power, Timothy J. 1998. "The Pen is Mightier than the Congress: Presidential Decree Authority in Brazil". In John Carey and Matthew Soberg Shugart, eds., Executive Decree Authority: Calling Out the Tanks or Filling Out the Forms? New York: Cambridge University Press.

Reich, Gary. 2002. "Executive Decree Authority in Brazil: How Reactive Legislators Influence Policy". Legislative Studies Quarterly, 27, pp. 5-31.

Singer, André. 2009. "Raízes Sociais e Ideológicas do Lulismo". Novos Estudos CEBRAP, 95, pp. 83-102.

Lúcio R. Renno is Associate Professor in the Research Center and Graduate Program on the Americas, CEPPAC, of the University of Brasilia. He received his Ph.D. in Political Science from the University of Pittsburgh in 2004. His publications on legislative politics, voting behavior and public opinion have come out in Comparative Political Studies, American Journal of Political Science, Legislative Studies Quarterly, Latin American Politics and Society, Journal of Politics, Journal of Latin American Studies, Journal of Legislative Studies, Electoral Studies, Dados - Revista de Ciencias Sociais, and Opinião Pública. He is co-editor of Reforma Politica: Lições da História Recente, Editora da FGV, Rio de Janeiro, 2006, Reforma Política em Questão, Editora da UnB, Brasília, 2008 and Legislativo Brasileiro em Perspectiva Comparada, Editora da UFMG, Belo Horizonte, 2009. 